\title{
Impact of nitrate ammonium and calcium (CAN27\%) on the environment.
}

\author{
Fares Redouane ${ }^{1}$, Bouadi Abed $^{2}$, Lounis Mourad ${ }^{1}$ \\ ${ }^{1}$ LAAR, University of Science and Technology - Mohammed Boudiaf - BP 1505 - Oran - Algeria \\ ${ }^{2}$ Centre universitaire Ahmed ZABANA RELIZANE, Algeria \\ E-mail: fares-redouane@hotmail.com
}

\begin{abstract}
In this research, a detailed study for energy consumption levels evaluation and environmental impacts assessment in the fertilizers production sector in Algeria was achieved. An analysis of the various inputs and outputs to the process to identify different sources of pollution throughout the life cycle of fertilizer was used. One product is making the subject in this study; CAN $27 \% \mathrm{~N}$. The flows of material and energy for each phase of the life cycle were counted and the associated environmental problems were identified. The analysis was conducted according to the LCA standards ISO (International Standard Organization) 14040 series and the impacts categories studied are Global Warming Potential, Acidification Potential, Troposphere Ozone Precursor Potential, and Resources use. The results show that Cumulative Energies Requirement and GHG emission in Algerian fertilizers production process are significant. Ammonia plant use $82 \%$ of total natural gas that is consumed by fertilizer manufactory. Production of ammonia per year requires $4,506.107 \mathrm{MJ}$ of electricity and $2,059.108$ of natural gas and generates $1.82 \mathrm{~T} \mathrm{CO} 2$ eq. (equivalent).
\end{abstract}

\section{Introduction}

The fertilizer industry is characterized by its high energy demand and the extensive greenhouse gas (GHG) emissions [1]. The European Commission estimates that fertilizer production consumes between $2 \%$ and $3 \%$ of global energy [2], and accounts for about $1.2 \%$ of global GHG emissions [3].

Such impacts can occur at the local, regional or global level inducing adverse or even dangerous effects on human health and its environment. Thus, an environmental assessment as well quantitative as qualitative is imperative and requires, an identification of the root causes of this degradation, a diagnosis establishment on the territory as vast and diversified as of Algeria. For this, a permanent follow-up is necessary to predict the trend of the receiving environment and recommend the appropriate remedies. These threats remain serious and generalize to deterioration of our living environment, Pollution of water, depletion of forest resources, extinction of plant and animal species, accumulation of chemicals that poison soils, desertification gaining more ground every day and fumes of toxic gases seriously altering the air we breathe. 
The concentration of human activities in areas in close seas proximity, like the Mediterranean Sea, has always had a long-term, high environmental impact resulting in degradation of the marine environment [4].

Modern civilization and the human activities are undeniably the main causes of the contamination of the atmosphere, hence the pollution of the air generated mainly by the discharges of industrial installations. This constantly growing pollution contributes to an imbalance of the ecosystem to bring about profound changes in the global climate. It should be noted that a large part of the domestic and industrial energy responsible for this pollution is produced by fossil fuel combustion processes, the result of which is obviously highly polluting pollutant species, such as carbon oxides (COx), nitrogen oxides ( $\mathrm{NOx}$ ), sulfur oxides $\left(\mathrm{SO}_{2}\right)$ and aerosols. [5]

However, coastal areas are exposed to enormous risks of pollution, the demographic pressure where the majority of the world's population is located near the coast, the growth of urban areas, coupled with a rapid expansion of industry and tourism, and a flared exploitation of marine resources [6]. Humanity has become sensitive of the fragility of this environment, especially since biological resources are often threatened, from where a large part of the economic resources (tourism, fishing, port activities) come from coastal areas [4].

ALGERIA is a traditionally agricultural country, and is resolutely committed from its independence in a process of industrialization aimed at getting the country out of the underdeveloped world and into the ranks of the industrialized nations. Most of the factories produced were indeed poorly established [6] and the criteria established at the time were obedient, most often to political considerations which in any case did not take into account environmental concerns.

Many industrial units have been established on the most fertile land and on water bodies and are now seriously threatened by pollution.

Indeed, the Algerian coast is relatively polluted. This pollution is the combination of several factors, but discharges of untreated industrial wastewater are the most important factor. Several authors [7], [8] have shown increasing pollution throughout the Algerian coastline, especially in the coastal areas of major cities.

On a global scale, the problem of climate change is much more complex to analyze and understand, mainly because of feedbacks, sources and sinks of non-identifiable greenhouse gases. It must be possible to supply the quantity needed for domestic and industrial consumption, to recycle wastewater as much as possible and to limit polluting discharges into the natural environment.

Better production and less polluting are the challenges facing industry in all sectors by politicians in charge of the environment and public opinion.

The constraints in legislative and normative form are more and more drastic. Industries as diverse as chemistry, petrochemicals, agribusiness, tanneries, metal waste industries or paper mills produce a wide variety of effluents that require new investigations and process development.

The fertilizer production sector has been the subject of several studies around the world aimed at assessing environmental impacts [9], and energy performance in their production processes [10], [11]. Fertilization has a significant impact on soil than on groundwater [12]. Soil salinity [13], heavy metal accumulation [14], water eutrophication [15], nitrate accumulation, and GHG emissions [16] are impacts caused by the excessive and uncontrolled use of fertilizers [17].

Nowadays, ammonia contributes significantly to the nutritional needs of terrestrial organisms by acting as a precursor to fertilizers, which is very accommodating to increase crop yields [19]. Ammonia is also a building block for the synthesis of many chemicals (nitric acid, ammonium chloride ...) and is used in many commercial cleaning products (in the form of salts, solutions or anhydrous). There are several manufacturers in the world 
producing 157 million tonnes of ammonia per year [20], of which Algeria provides $0.4 \%$ [4].

Worldwide, ammonia production is mainly synthesized by the Haber-Bosch process [9]. Natural gas is the main raw material for ammonia production, accounting for nearly $80 \%$ of global ammonia production [10]. However, it is a process of energy discharge and mainly causes the production of greenhouse gases (GHG). In fact, ammonia production is responsible for about $0.93 \%$ of global GHG emissions [19]. About 1.5 tonnes of $\mathrm{CO}_{2}$ are emitted into the atmosphere during the production of 1 tonne of ammonia [21]. Greenhouse gas emissions from fertilizer production are expected to increase before stabilizing due to growing demand for sustainable food supplies for a growing world population [21]. The increase in greenhouse gases (GHG) in the atmosphere is one of the major environmental problems affecting the world's population during this century [22].

Recently, the fertilizer production (ammonia production) sector has been addressed by several authors ([23], [3], [24]). Based on the results of these studies, [1] concluded that the production of one ton of ammonia requires an average energy consumption of $25 \times 10^{3}$ to $35.10^{3}$ MJ. In 2007, [25] exploited an average global energy consumption of $36,9 \times 10^{3} \mathrm{MJ} / \mathrm{T}$. [26] estimated average energy consumption for ammonia production in Europe of around 34.7 GJ/T. These studies have focused on GHG emissions assessment and primary resource needs. In addition, inventories of inputs used in these studies are based on bibliographic data or simple estimates [1].

Life cycle assessment assesses the environmental impacts generated by a production process or service. The primary benefit of LCA is its ability to account for all productrelated inputs and emissions in a particular function throughout its "cradle to grave" lifecycle. It is commonly used to perform a complete emission assessment (standardized method for the ISO series international standards system).

\section{Methodology}

This investigation presents a LCA of liquid ammonia produced in Algeria (Arzew fertilizer production complex). It is based on an inventory with primary data and aims to assess the environmental impacts associated with the product life cycle compared to previous studies. Several impact categories that have been studied in this study are: resource use, global warming potential, acidification potential, and the precursor potential of troposphere ozone. As noted above, all studies have been devoted to GHG emissions assessment and, due to the lack of results of the impact of the troposphere ozone impact in the bibliography; the results comparison will be summarized in the comparison of GHG emissions and energy needs. This will enable us to assess the extent of the environmental impact of the Algerian ammonia production process and determine its environmental position relative to other plants around the world.

An LCA has been developed and implemented from the ISO 14040 standard. ISO 14040: 2006 specifies the principles and framework for performing the life cycle assessment. ISO 14044: 2006 establishes the requirements and provides guidelines for performing an LCA. The latter consists of four phases: the definition of the objectives and scope of the study, the life cycle inventory, the life cycle impact assessment and the life cycle interpretation [27], (ISO, 2006a, 2006b).

\section{Selection and description of study area}

The complex Fertial (Arzew) specialized in the production of ammonia, nitric acid, ammonium nitrate, and urea, is located on the Arzew industrial platform $40 \mathrm{~km}$ west of 
Oran, $3 \mathrm{~km}$ east of Arzew, and $4 \mathrm{~km}$ west of Bethioua and is close to the sea. This region is one of the most polluted areas of the Algerian coast. [4]

The region of Arzew is characterized by a moderate climate. Generally, the minimum air temperature does not fall below $0{ }^{\circ} \mathrm{C}$ and the maximum does not exceed $40^{\circ} \mathrm{C}$ The average annual temperature is $18.5^{\circ} \mathrm{C}$, with average monthly extremes of $28.8^{\circ} \mathrm{C}$ in August [28]. The winds on Arzew blow from West to Southwest. In December southwest winds from $7 \mathrm{~h}$ to $18 \mathrm{~h}$ : west and south winds at $13 \mathrm{~h}$. The same remarks can be noted for the months of January, November, March, April and May. Nevertheless, for the last three months, Northeast winds have been recorded [28]. According to the months of drought are the predominantly north-easterly months. There are, moreover, warm winds from the South and Southwest. These are hot and dry winds from 09 to 16 days a year.

In addition, wind is one of the forces governing currents and swells. The latter constitute a very important ecological factor along the Algerian coastline in the absence of permanent currents and tides since they are the only active ones in the bays and gulfs of the offshore coast.

\section{Results and Interpretation}

\subsection{Resources use}

\subsubsection{Ammonia}

The production of one ton of ammonia requires cumulative material demand and cumulative energy demand which are shown in both tables below:

Cumulative Material Request

Table 1. Cumulative material Requirement (CMR) for one tone of ammonia

\begin{tabular}{|c|c|c|c|c|}
\hline \multirow{5}{*}{ 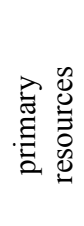 } & resources & Qnt & Unit & $\%$ \\
\hline & natural gas & 0,518 & $\mathrm{~T}$ & $27,34 \%$ \\
\hline & water & 1,06 & $\mathrm{~T}$ & $49,30 \%$ \\
\hline & $\mathrm{N} 2$ & 0,5 & $\mathrm{~T}$ & $23,25 \%$ \\
\hline & Total & 2,07 & $\mathrm{~T}$ & \\
\hline
\end{tabular}

Cumulative Energy Request

Table 2. Cumulative Energy Requirement (CER) for one tone of ammonia

\begin{tabular}{|l|r|l|r|}
\hline resources & \multicolumn{1}{|l|}{ Qnt } & Unit & \multicolumn{1}{c|}{$\%$} \\
\hline natural gas & 26,349 & GJ & $50,72 \%$ \\
\hline combustible gas & 25,596 & GJ & $49,27 \%$ \\
\hline process fuel & 20,608 & GJ & $39,67 \%$ \\
\hline HP (High Pressure) & 0,167 & GJ & $0,32 \%$ \\
\hline electricity generation & 4,82 & GJ & $9,27 \%$ \\
\hline
\end{tabular}




\subsubsection{Nitric acid}

The production of one tone of nitric acid requires $7.47 \mathrm{t}$ of primary natural resources.

Table 3: Cumulative material Requirement (CMR) for one ton of nitric acid

\begin{tabular}{|c|c|c|c|c|}
\hline \multirow{5}{*}{ 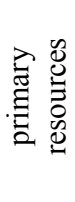 } & resources & Unité & Qnt & $\%$ \\
\hline & natural gas & $\mathrm{T}$ & 0,166 & $2,22 \%$ \\
\hline & HP & $\mathrm{T}$ & 2,1 & $28,11 \%$ \\
\hline & air $(\mathrm{O} 2)$ & $\mathrm{T}$ & 5,2 & $69,61 \%$ \\
\hline & Total & $\mathrm{T}$ & 7.47 & \\
\hline
\end{tabular}

The energy requirement in the nitric acid production process is of the order of 20.42 $\mathrm{GJ} / \mathrm{T}$ of acid nitric acid, $36.43 \%$ of which is $7.44 \mathrm{GJ}$ is used as raw material; the rest is consumed as fuel in production processes. Gas is the main source of energy used by 20.41 GJ or $99.95 \%$.

\subsubsection{Calcium ammonium nitrate CAN $(27 \% N)$}

Production of one tone of CAN 27\% requires $6.07 \mathrm{t}$ of primary natural resources

Table4. Cumulative Demand for Materials (CCD) for one tone of CAN 27\%

\begin{tabular}{|c|c|c|c|c|}
\hline \multirow{5}{*}{$\begin{array}{l}\tilde{U} \\
0 \\
\vdots \\
0 \\
0 \\
0\end{array}$} & \multirow{2}{*}{ renewable } & water & 1,86 & $T$ \\
\hline & & $\operatorname{air}(\mathrm{O} 2)$ & 3,77 & $\mathrm{~T}$ \\
\hline & \multirow{3}{*}{ Non-renewable } & natural gas & 0,01 & $\mathrm{~T}$ \\
\hline & & calcium carbonate & 0,21 & $\mathrm{~T}$ \\
\hline & & $\mathrm{CaCO}_{3}$ & 0,22 & $\mathrm{~T}$ \\
\hline
\end{tabular}

The cumulative energy Requirement (DER) is 23.12 GJ/T of CAN 27\%, this quantity is mainly used to supply energy to the system (electricity generation, steam production), energy non-renewable (natural gas) have $99.99 \%$ of DER, the consumed amount of natural gas is 23.09 GJ or $99.87 \%$ of total DER.

The quantities of the main pollutants and their percentages emitted during the production of each unit are illustrated in the following table 
Table 5. Quantities and percentages of major pollutants emitted from each unit

\begin{tabular}{|c|c|c|c|c|c|c|c|}
\hline \multirow{2}{*}{\multicolumn{2}{|c|}{$\begin{array}{c}\text { Units } \\
\text { pollutants }\end{array}$}} & \multicolumn{2}{|c|}{ Ammonia $(\mathrm{t} / \mathrm{t})$} & \multicolumn{2}{|c|}{ Acid nitric $(t / t)$} & \multicolumn{2}{|c|}{$\operatorname{CAN}(\mathrm{t} / \mathrm{t})$} \\
\hline & & \multirow{2}{*}{$\begin{array}{r}\text { Qnt } \\
1,89 \\
\end{array}$} & \multirow[t]{2}{*}{$\%$} & \multirow{2}{*}{$\begin{array}{r}\text { Qnt } \\
2,78 \\
\end{array}$} & \multirow[t]{2}{*}{$\%$} & \multirow{2}{*}{$\begin{array}{l}\text { Qnt } \\
2,22 \\
\end{array}$} & \multirow[t]{2}{*}{$\%$} \\
\hline \multirow{4}{*}{ 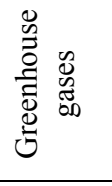 } & $\mathrm{CO}_{2} \mathrm{eq}$ & & & & & & \\
\hline & $\mathrm{CO}_{2}$ & 1,75 & $92,85 \%$ & 0.71 & $25,21 \%$ & 0,839 & $37,80 \%$ \\
\hline & $\mathrm{CH}_{4}$ & 0,11 & $5,80 \%$ & 2,00 & $72,08 \%$ & 1,31 & $59,11 \%$ \\
\hline & $\mathrm{N}_{2} \mathrm{O}$ & 0,02 & $1,30 \%$ & $7,2610^{-2}$ & $2,61 \%$ & $6,6810^{-2}$ & $3,01 \%$ \\
\hline \multirow{4}{*}{ 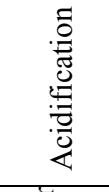 } & $\mathrm{SO}_{2} \mathrm{eq}$ & $3,4010^{-4}$ & & $4,92910^{-3}$ & & $5,6410^{-3}$ & \\
\hline & NOx & $3,3410^{-4}$ & $98,10 \%$ & $4,55110^{-3}$ & $92,33 \%$ & $5,2310^{-3}$ & $92,70 \%$ \\
\hline & $\mathrm{SO}_{2}$ & $6,39210^{-6}$ & $1,88 \%$ & $2,6110^{-4}$ & $5,29 \%$ & $7,3310^{-5}$ & $1,30 \%$ \\
\hline & $\mathrm{NH}_{3}$ & $1,2210^{-13}$ & $0,00 \%$ & $1,1310^{-4}$ & $2,30 \%$ & $3,3310^{-4}$ & $5,90 \%$ \\
\hline \multirow{5}{*}{ 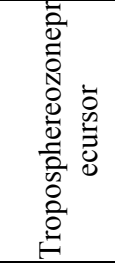 } & TOPP eq & $5,7510^{-3}$ & & $5,5310^{-3}$ & & $5,2410^{-3}$ & \\
\hline & $\mathrm{CH}_{4}$ & $7,0610^{-4}$ & $12,27 \%$ & $1,0910^{-4}$ & $1,97 \%$ & $5,1410^{-5}$ & $0,98 \%$ \\
\hline & NOx & $4,6810^{-3}$ & $81,34 \%$ & $5,2810^{-3}$ & $95,40 \%$ & $5,0010^{-3}$ & $95,50 \%$ \\
\hline & $\mathrm{CO}$ & $2,2710^{-4}$ & $3,95 \%$ & $8,0210^{-5}$ & $1,45 \%$ & $1,2110^{-4}$ & $2,30 \%$ \\
\hline & NMVOC & $1,3510^{-4}$ & $2,35 \%$ & $6,3610^{-5}$ & $1,15 \%$ & $6,2910^{-5}$ & $1,20 \%$ \\
\hline
\end{tabular}

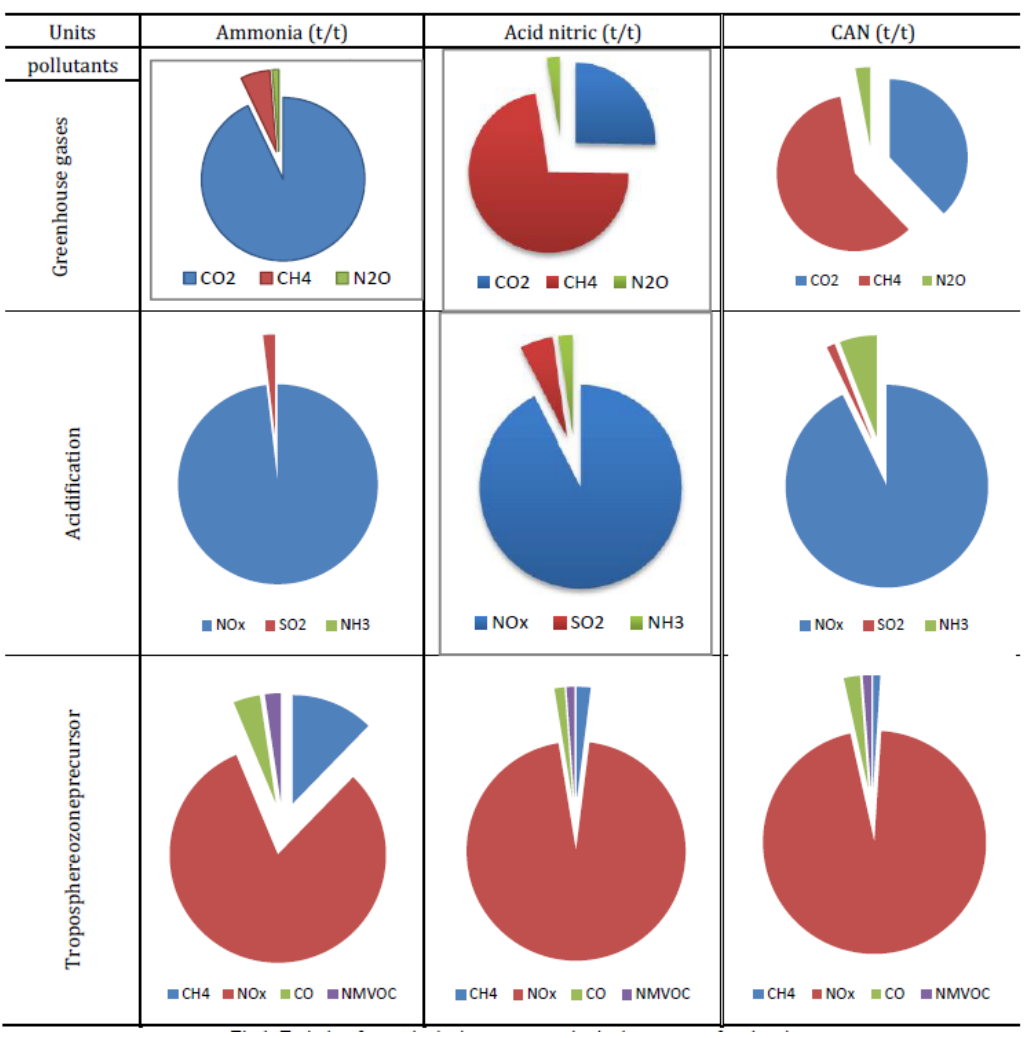

Figure.1. Emission factors in the impact categories in the process of each unit

Table 6 below shows the CO2eq emission rate for the production of one ton of ammonia in some previous studies, and compared it with the result obtained by our investigation. 
Table 6. Comparison of $\mathrm{CO}_{2}$ eq emissions with previous studies

\begin{tabular}{|c|c|c|c|}
\hline Region & Value & Unit & Reference \\
\hline World average & 2,07 & \multirow{7}{*}{$\begin{array}{c}\mathrm{T} \mathrm{CO}_{2} \mathrm{eq} / \mathrm{T} \text { of } \\
\text { ammoniac }\end{array}$} & [25] \\
\hline Europe & 1,95 & & [26] \\
\hline USA & 1,26 & & [29] \\
\hline Canada & 1,6 & & [30] \\
\hline Australia & 1,8 & & [11] \\
\hline Netherlands & 2,16 & & [32] \\
\hline Fertial-Arzew & 1,89 & & \\
\hline
\end{tabular}

Table 7 illustrate the rate of $\mathrm{N}_{2} \mathrm{O}$ emission for production the production of one ton of nitric acid for different previous study and compare it with our investigation. We find that the emission of $72.6 \mathrm{Kg}$ of $\mathrm{N}_{2} \mathrm{O}$ on the production of 1 ton of nitric acid and significantly higher than the global standard which appears in the following table.

Table 7. Comparison of $\mathrm{N}_{2} \mathrm{Oéq}$ emission with previous studies

\begin{tabular}{|c|c|c|c|}
\hline Region & Value & Unit & Reference \\
\hline World & 9 & \multirow{4}{*}{$\begin{array}{c}\mathrm{kg} \mathrm{N}_{2} \mathrm{O} / \mathrm{T} \\
\mathrm{HNO}_{3}\end{array}$} & [30] \\
\hline Europe & 21.6 & & [26] \\
\hline USA & 9 & & {$[10]$} \\
\hline Fertial-Arzew & 72.6 & & \\
\hline
\end{tabular}

In present study, we determined an emission average of 2.22 tones of $\mathrm{CO}_{2}$ eq for one tone of CAN, and refer to a study by [9] where they calculated the carbon dioxide footprint for several places; most of the results are shown in Table 8 below

Table 8. Eq CO2 emission for the production of one tone of CAN [9]

\begin{tabular}{|l|c|c|}
\hline \multicolumn{1}{|c|}{ Region } & Value & Unit \\
\hline World average & 2,567 & \\
\hline Europe & 2,208 & \\
\hline Russia & 2,565 & \multirow{2}{*}{$\mathrm{CO}_{2}$ eq/T CAN } \\
$27 \%$
\end{tabular}

\section{Conclusion}

The objective of this study is to evaluate the degree of pollution in the gaseous effluents of the FERTIAL-ARZEW complex known by its diversity in mineral fertilizer manufacturing processes.

The fertilizer industry occupies an important place in the development of local economies through its essential role as a producer of the basic elements for the development of the agricultural sector. This work provides an overview of the 
environmental issue in the fertilizer production sector. It has been realized to enrich the theoretical and practical knowledge on the evaluation of environmental problems of sector. Knowledge of the nature and quantities of raw materials used and substances emitted into the environment by the fertilizer industry in Algeria.

The space-temporal monitoring of several physicochemical factors has given us the image of a relatively intense pollution which results in a significant organic and mineral load. The results of the various analyzes carried out revealed the presence of a large high concentration of $\mathrm{N}_{2} \mathrm{O}$ in the exhaust gas was noted at the level of the evacuated gases.

The need to use a credible environmental assessment tool and especially to take into account all the production processes used by the sector seems essential. The use of Life Cycle Analysis is the most appropriate method of the moment for such an objective. Its global vision enables it to analyze the inputs and outputs of a production process, to take into account input data from upstream processes and to add the impact related to its processes during the evaluation.

The application of LCA on the production of fertilizers and chemicals "Fertial-Arzew" attests to the use of conventional production processes, with a high consumption of raw materials. This results in overconsumption of non-renewable energy (natural gas) main fuel for the production of HP (High Pressure) steam and ammonia.

In order to address these industrial pollution problems, the development of sound remediation processes downstream of the fertilizer manufacturing process should be a priority for this industry. In addition, an information and warning system on pollution peaks must be set up in the FERTIAL complex's environmental management program. As a result of this study, it appears that the production of fertilizers consumes large amounts of fossil energy and therefore generates GHGs.

The ammonia unit accounts for $75 \%$ of Fertial-Arzew's total production, and consumes $78 \%$ of the company's natural gas. Ammonia is therefore the main product of the company. The production of one tonne of ammonia contributes mainly to global warming by the emission of about $1.89 \mathrm{t} \mathrm{CO} 2$ eq of GHGs, and to the depletion of resources by the consumption of $51.94 \mathrm{GJ}$ of natural gas. The latter is $25.16 \%$ higher than the world average of $41.5 \mathrm{GJ} / \mathrm{T}$ of ammonia. In light of these results, it can be considered that the ammonia unit is the main source of environmental impact in terms of GHG emissions and natural resource use.

The reasons for this overconsumption of energy lie in two factors; the first is related to the dilapidated facilities since 1982, which forces the unit has restarted following frequent breakdowns. A second factor relates to gas reforming operations, operations that contribute mainly to the depletion of natural resources on one side and GHG emissions on the other side. This may be due to the low efficiency of the catalytic reaction, in which the catalysts are used for more than 10 years.

In the light of the results we have obtained and studies previously carried out, certain aspects should be developed and deepened:

The upgrading of industrial equipment and its regular maintenance and the replacement of catalysts in the production units (particularly in the ammonia and nitric acid unit) are two links in the chain of the cycle which will ensure a better performance of production units and contribute to the reduction of natural gas consumption and consequently the reduction of GHG emissions.

\section{References}

1. Wood S, Cowie .A., A review of greenhouse gas emission factors for fertilizer production. Cooperative Research Centre for Greenhouse Accounting, for IEA 
Bioenergy Task 38,2004. On line at: http://www.ieabioenergy task38.org/publications/GHG_Emission_Fertil-izer\%20Production_July2004.pdf,

2. IPPC, Intergovernmental Panel on Climate Change (IPCC). Reference Document on Best Available Techniques for the Manufacture of Large Volume Inorganic Chemicals - Ammonia, Acids and Fertilizers. BREF 08.07. Integrated Pollution Prevention and Control, under the European Commission. 2007.

3. Kongshaug G., Energy consumption and greenhouse gas emissions in fertilizer production.Proceedings on IFA Technical Conference, Marrakech, Morocco. 28-09 to 01-10, 1998.

4. FARES R., LOUNS M., Pollution characterization of liquid wastes of the factory complex fertial (Arzew, Algeria): J Air Wast Manage Assoc,2016, 66: 260-266

5. FARES R., Aissa A., Characterization of Gaseous Pollutants from the Fertilizer Complex Fertial (Arzew-Algeria) Environ SciInd J. 2017; 13(5):151.

6. FARES R., LOUNS M., Determination of the Sea Waters Quality of Arzew-Algeria Gulf. J Pollut Eff Cont 5: 188. 2017, doi: 10.4176/2375-4397.1000188

7. BAKALEM A., GRIMES S., La pollution en milieu portuaire : les peuplements macrobenthiques du port de Skikda (Algérie). Workshop «Circulation des eaux et pollution des côtes méditerranéennes des pays du Maghreb ». Rabat 9-11 Nov. 1992, Eds INOC Izmir (Turquie), 1993,195- 202.

8. GRIMES S., Peuplements benthiques des substrats meubles de la côte algérienne : taxonomie, structure et statut écologique. Thèse Doctorat, Univ. Oran ; Département de Biologie. 2010, 360p.

9. Kool A, Marinussen M, Blonk H., LCI data for the calculation tool Feed print for greenhousegas emissions of feed production and utilization. GHG Emissions of N, P and $\mathrm{K}$ fertilizer production. GravinBeatrixstraat 34, 2805 PJ Gouda, Netherlands: Blonk Consul-tants; 2012.

10. IEA (International Energy Agency), Tracking industrial energy efficiency and $\mathrm{CO} 2$ emissions. 2007,p. 324.

11. EFMA, (European Fertilizer Manufacturers' Association), Production of Ammonia. Booklet No. 1 of 8: Best Available Techniques for Pollution Control in the European FertilizerIndustry. B-1160 Brussels, Belgium: Ave. E van Nieuwenhuyse. 2000.

12. Barros R, Isidoro D, Aragüés R.,. Irrigation management, nitrogen fertilization and nitrogen losses in the return flows of La Violada irrigation district (Spain). Agriculture, Ecosystems \&Environment: 2012, 155(15): 161-171

13. Ammari T.G, Tahhan R, Abubaker S, Al-zubi Y, Tahboub A, Taany R, Abu-Romman S, Al-Manaseer N, Stieiya M.H., Soil Salinity Changes in the Jordan Valley Potentially Threaten Sustainable Irrigated Agriculture. Pedosphere. 2013: 23(3): 376-384.

14. Gupsa D.K, Chatterjee S, Datta V, Walther C., Role of phosphate fertilizers in heavy metal uptake and detoxification of toxic metals. Chemosphere: 2014, 108: 134-144.

15. Smith V.H., Reference Module in Earth Systems and Environmental Sciences. Eutrophication: 2009, 61-73.

16. Kahrl F, Yunju L, Yufang S, Tennigkeit T, Wilkes A, Jianchu X., Greenhouse gas emissions from nitrogen fertilizer use in China. Environmental science \& policy: 2010, 13: 688-694.

17. Savci S., Investigation of Effect of Chemical Fertilizers on Environment. Procedia APCBEE: 2012, 1: 287-292.

18. Gilbert P, Thornley P., Energy and carbon balance of ammonia production from biomass gasification, Bio-ten., Holiday Inn, Birmingham, 2010. On line at: https://www.escholar.manchester.ac.uk/api/datastream?publicationPid=uk-ac-man-scw: 91274\&datastreamId=FULL-TEXT.PDF. 
19. IFA, International Fertilizer Industry Association (IFA)., Production and international trade committee. world pa statistics by country in ' 000 tones product. Potash public. 2014c. On line at: http://www.fertilizer.org/en/doc_library/Statistics/PIT/Potash_public.xlsx

20. Anderson K, Bows A, Mander S., From long-term targets to cumulative emission pathways: reframing UK climate policy. Energy Polic, 2008, 36(10): 3714-3722.

21. Gilbert P, Alexander S, Thornley P, Brammer J. Assessing economically viable carbon re-ductions for the production of ammonia from biomass gasification. J Clean Prod 2014;64:581-9.

22. De Morais RF, Boddey RM, Urquiaga S, Jantalia CP, Alves BJR., Ammonia volatilization and nitrous oxide emissions during soil preparation and $\mathrm{N}$ fertilization of elephant grass (PennisetumpurpureumSchum.). Soil BiolBiochem, 2013, 64: 80-8.

23. Davis J, Haglund C., Life Cycle Inventory (LCI) of Fertiliser Production. Fertiliser Products Used in Sweden and Western Europe.. Master's Thesis, Chalmers University of Technology. SIK-Report No. 654. 1999.

24. Patyk A., Balance of Energy Consumption and Emissions of Fertilizer Production and Supply. Reprints from the International Conference of life cycle assessment in agriculture, food and non-food agro-industry and forestry: achievements and prospects, Brussels, Belgium. 1996.

25. Williams G, Al-Ansari F., IFA Benchmarking of Global Energy Efficiency in Ammonia Production. Workshop on Energy Efficiency and CO2 Reduction Prospects in Ammonia Production, In. Ho Chi Minh City, Vietnam: IFA Technical Committee Meeting, 2007.

26. Haas MJGde, van Dijk TA., Inventarisatieklimaatvriendelijkekunstmest. Wageningen: Nutriënten Management Instituut NMI, 2010.

27. FinnvedenG,Michael Z, HauschildM, Ekvall T, Guinée J, Heijungs R., Recent developments in life cycle assessment. J Environ Manag, 2009, 91(1):01-21.

28. TAGHEZOUT Fatima, Impact Environnemental Des Rejets D'eau Le Long Du Littoral Occidental Algérien, mémoire de magister, Université d'Oran. Faculté des Sciences de la Nature et de la Vie Département de Biologie. 2015,170p

29. EPA (US Environmental Protection Agency). Synthetic Ammonia, AP-42. 5th ed. vol. 1. Chapter 8: Inorganic chemical industry; 1993.

30. IPPC, Intergovernmental Panel on Climate Change (IPCC). Reference Document on Best Available Techniques for the Manufacture of Large Volume Inorganic Chemicals - Ammonia, Acids and Fertilizers. BREF 08.07. Integrated Pollution Prevention and Control, under the European Commission. 2007.

31. Kramer KJ, Moll HC, Nonhebel S., Total Greenhouse Gas Emissions Related to the Dutch Crop Production System. AgricEcosyst Environ, 1999. 